\title{
Investigation of Cytotoxic Effects of Curcuma Longa, Zingiberaceae and Dianthus Caryophllus, Which are Commonly Used as Food Supplements in Daily Life
}

\author{
Özgür ALBUZ* \\ Keçören Training and Research Hospital, Department of General Surgery, 06000, Ankara, Turkey
}

\begin{abstract}
The aim of this study is to investigate the cytotoxic effects, which have an important place, in terms of public health as using herbal food supplement, of ginger, turmeric and clove seeds over healthy cells. In this study, designed as an in vitro cell culture study, fibroblast cells were used to investigate the effect of plant extracts on healthy cells. MTT cell viability test was used to determine cytotoxicity. The MTT test was performed according to ISO 10993-5 standards and when the cell viability was calculated to be below 70\% in the MTT method, the sample was considered potential cytotoxic. When the viability values calculated according to the absorbance values obtained from MTT test are examined; It was calculated that ginger and turmeric extracts were not cytotoxic at any concentration, including the highest concentrations. On the other hand, it was calculated that 1:2 concentration of clove extract was cytotoxic and the viability was $26.7 \%$. As a result of this study, it has been found that clove use is remarkable in terms of plant nutritional supplements with its current use in terms of cytotoxic effect compared to turmeric and ginger.
\end{abstract}

Keywords: Curcuma Longa, Zingiberaceae, Dianthus Caryophllus, Cytoxicity

\section{$* * *$ \\ Günlük Yaşamda Gıda Takviyesi Olarak Kullanılan Zencefil, Zerdeçal ve Karanfilin Sitotoksik Etkilerinin Araştırılması}

ÖZ

Bu çalışmanın amacı, günlük yaşamda gıda takviyesi olarak kullanılan ve halk sağlığı açısından önemli bir yeri olan zencefil, zerdeçal ve karanfil tohumlarının sağlıklı hücreler üzerinde sitotoksik etkilerini araştırmaktır. İn vitro hücre kültürü çalsşması olarak tasarlanan bu çalışmada, bitki özlerinin sağlıklı hücreler üzerindeki etkisini araştırmak için fibroblast hücreleri kullanılmıştır. Sitotoksisiteyi belirlemek için MTT hücre canlılığı testi kullanılmıştır. MTT testi ISO 10993-5 standartlarına göre yapıldı ve MT'T yönteminde hücre canlıllğı \% 70'in altında olduğu hesaplandığında, numunenin sitotoksik potansiyelde olduğu kabul edilmiştir. MTT testinden elde edilen absorbans değerlerine göre hesaplanan canll1ık değerleri incelendiğinde; Zencefil ve zerdeçal ekstrelerinin, en yüksek konsantrasyonlar dahil olmak üzere herhangi bir konsantrasyonda sitotoksik olmadığ1 hesaplanmıstır. Öte yandan, 1:2 oranında karanfil ekstresi konsantrasyonunun sitotoksik ve canlılı̆̆ı \% 26.7 olduğu hesaplanmışır. Bu çalışma sonucunda, özellikle karanfil kullanımının zerdeçal ve zencefil ile karşılaştıııldığında sitotoksik etkiye sahip olması bakımından mevcut kullanımıyla, bitkisel gıda takviyeleri açısından dikkate değer olduğu tespit edilmiştir.

Anahtar Kelimeler: Zerdeçal, zencefil, karanfil, sitotoksitite

To cite this article: Albuz Ö. Investigation of Cytotoxic Effects of Curcuma Longa, Zingiberaceae and Dianthus Caryophllus, Which are Commonly Used as Food Supplements in Daily Life. Kocatepe Vet J. (2019) 12(3):351-356 


\section{GİRİŞ}

Halk sağllğı açısından dengeli beslenme son derece önemlidir. Besin tüketiminde besinlerin bileşimi hakkında güvenilir veri gerektirir. $\mathrm{Bu}$ veriler aynı zamanda, farklı besinler için gıda kaynakları hakkında gerekli bilgileri içeren sağlıklı beslenme için gıdaya dayalı beslenme kilavuzlarının da temelleridir (Elmadfa ve Meyer 2010). Zerdeçal (Curcuma longa Linn. Syn C. domestica Valeton), Hindistan'da yaygin olarak kullanilan gida koruyucu, renklendirici ve baharat olarak kullanilan bir bitkidir (Aggarwal ve ark. 2007, Chattopadhyay ve ark. 2004). Bununla birlikte geleneksel tıp içerisinde de birçok tıbbi tedavi edici özellik bu baharata bağlanır (Balaji, 2010, Chattopadhyay ve ark. 2004). Curcumin'in genel tibbi özelliği; antioksidan, antienflamatuar, antiviral ve antifungal etkilere sahip olmasına bağlanmaktadır (Akram ve ark. 2010).

Zencefil'de geleneksel tıp içerisinde ve gida takviyesi olarak kullanılan bir diğer bitki olup (Zingiber officinale Rosc.), Zingiberaceae ailesine aittir. Bu bitkinin GüneyDoğu Asya'da ilk olarak kullanıldığı, daha sonraları baharat olarak birçok ülkede yemeğe lezzet katmak için yaygın biçimde kullanıldığı ifade edilmektedir (Park ve Pizzuto 2002). 45'den fazla cins ve 800 alt türe sahip (Haniadka ve ark. 2013) ortalama 30 ila 90 $\mathrm{cm}$ yüksekliğinde yetişen dik, çok ylllık bir bitkidir; Sarımsı, mor dudaklı çiçeklerden oluşan nadiren çiçek açan yeşilimsi sarı saçaklara sahiptir (Tyler ve Foster 1993). Hindistan'da ve taze ve kurutulmuş köklerin farklı tıbbi ürünler olarak kullanıldığı gibi, Çin'de de kullanımı yaygindır. Bunun yanı sıra, zencefil rizomu da geleneksel bitkisel ilaçlarda kullanılmıştır. Zencefilin sağllğı teşvik eden bakış açısı, zengin fitokimyasina atfedilmektedir (Shukla ve Singh 2009). Jolad ve ark. (2004) taze zencefili iki geniş kategori, yani uçucu ve uçucu olmayan kategoriler halinde gruplandırılmış. Uçucu maddeler, zencefilin farklı aromasını ve tadını sağlayan seskiterpen ve monoterpenoid hidrokarbonları içermektedir. Aksine, uçucu olmayan keskin bileşikler arasında gingeroller, shogaoller, paradoller ve zingerone bulunmaktadır. Laboratuvar hayvanlarında, zencefil gastrointestinal sistemin hareketliliğini arttırmakta ve analjezik, yatıştırıcı, antipiretik ve antibakteriyel özelliklere sahip olduğu ifade edilmektedir. Ayrıca zencefil yağının farelerde cilt kanserini önlediği kanıtlanmıştır. Michigan Üniversitesi'nde yapılan bir araştırma, gingerollerin yumurtalı kanseri hücrelerini öldürebildiğini göstermiştir (Ahmed ve ark. 2011).

Diğer bitkisel gida takviyesi olan karanfil (Dianthus caryophllus)'de son derece yaygin kullanilmaktadır. $\mathrm{Bu}$ bitkinin temel özelliklerine bakıldığında; yavaş bir oranda $0,5 \mathrm{~m}$ ile $1 \mathrm{~m}$ 'ye kadar büyüyen çok ylllık bir bitkidir. Temmuz-Ağustos ayları arasında çiçeklenmekte ve tohumlar Ağustos-Eylül aylarında olgunlaşmaktadır. Türleri hermafrodittir ve Lepidoptera denilen güveler ve kelebekler tarafindan tozlaştırılır. Bitki kendi kendine verim verme özelliğindedir. Bu sebeple yaban hayatına uyum sağlayabilen nadir bitkilerdendir. Uyumlu olduğu toprak yapısı hafif (kumlu), orta (loamy) ve ağır (kil) topraklar ve iyi drene topraklardır. Gölgede büyüyemezler ve kuru veya nemli toprağ1 tercih eder. Bitki atmosferik kirlenmeyi tolere edebilir (Fern 1997, Polunin ve ark. 1965, Zhu ve ark. 1998).

Karanfil bitkisi, geleneksel tıpta kullanilan bitkilerden biri olan Caryophyllaceae familyasina aittir. Karanfil ağacı Endonezya ve Pasifik adalarına özgüdür. Ayrıca güzelliği sebebiyle dünya çapında süs ağacı olarak yetiştirilmektedir (Mohammed ve Al-Bayati 2009). Yapılan çalışmalarda; antikanser, antiviral, antibakteriyal, antioksidan ve renoprotektif etkilerinden bahsedilmiştir (Al-Snafi 2017). Dünyada çok sayıda hasta sağlık amaçlı şifalı bitkiler kullanmaktadır. Bu nedenle, terapötik potansiyelleri, biyolojik özellikleri ve güvenilirliklerinin bilimsel incelemesi, doğru kullanımları hakkında çalışmalar halen sürmektedir (Gopal ve ark. 2019). Bu sebeple, günlük yaşamda gida takviyesi olarak kullanılan ve halk sağlığı açısından önemli bir yeri olan zencefil, zerdeçal ve karanfil tohumlarının sağlıklı hücreler üzerinde sitotoksik etkilerinin belirlenmesi amaçlanmıştır.

\section{MATERYAL ve METOD}

DMEM Medium (Biological İndustries, ABD), Trypsin EDTA Solution c (Biological İndustries, ABD), Foetal Bovine Serum (Biological İndustries, $A B D)$, Pen-Strep Solution (Biological İndustries, $\mathrm{ABD}$ ), fosfat tamponlu tuz çözeltisi (PBS), sitotoksisite testleri için; MTT, hücre kültürü çalışmaları için biyolojik güvenlik kabini (Esco, Class II BSC), CO2'li inkübatör (Binder, ABD), santrifüj (Hettich, Rotina 380R, Almanya), tekrarlayıc1 pipet (Gilson, Repetman, ABD), çok kanallı pipet (Gilson, PipetmanUltra, ABD), sitotoksisite çalışmaları için; mikroplaka okuyucu (Biotek, PowerWave XS2, $\mathrm{ABD})$. Hücre kültürü çalışmalarının tamamı, kültür kapları ve çoklu kuyucuklu plakalarda (Corning, $\mathrm{ABD})$ gerçekleştirilmiştir.

Aktardan temin edilen Zencefil, Zerdeçal ve Karanfil, TS EN ISO 10993- 12 standardında belirtildiği şekilde numunelerden $0,2 \mathrm{~g} / \mathrm{ml}$ olacak şekilde tartılarak 37 ${ }^{\circ} \mathrm{C}$ 'de 24 saat inkübe edilmiştir. Elde edilen ekstraktlar in vitro testlerde kullanılmıştır.

MTT: Sitotoksisiteyi belirlemek için TS EN ISO 10993-5 standartlarına uygun şekilde MTT testi yapıldı. Bu test hücre proliferasyonunun ölçülmesi için 3,[4,5-dimethylthiazol-2-yl]-2,5 diphenyltetrazolium bromide (MTT) tetrazolyum tuzu'nun kullanıldığ1 hassas bir metod olup eğer 
canlılik \%70'in altında hesaplanırsa numune sitotoksik potansiyele sahip olduğunu göstermektedir.

Kırıkkale Üniversitesi Bilimsel ve Teknolojik Araştırmalar Uygulama ve Araştırma Merkezi Biyouyumluluk Laboratuvarı hücre kütüphanesinde kriyotüpler kullanılarak $-80^{\circ} \mathrm{C}$ de dondurularak saklanan L929 (Fare adipoz sağliklı fiboblast hücre hatı) hücreleri, dondurucudan alınarak çözülmesi sağlanmış olup DMEM içerisinde \%89 DMEM, \%10 FBS ve \% 1 penisilin streptomisin olacak şekilde besiyeri hazırlanmıştır. Çözülme işlemi gerçekleştirilirken hücreler falkon tüp içerisine alındıktan sonra $4 \mathrm{ml}$ hazırlanmış olan besiyerinden eklenmiştir. Bu işlemden sonra hücrelerin bulunduğu falkon tüp 2000 rpm'de 2 dakika santrifüj edilmiştir. Santrifüj işleminin ardından falkon içerisinde bulunan süpernatant atılmış ve pellet besiyeri ile süspanse edilerek flaska aktarılmıștır. $37^{\circ} \mathrm{C}$ de $\% 5 \mathrm{CO}_{2}$ içeren inkübatöre alınan flasklar 24 saatte bir kontaminasyon ve hücre çoğalmalarının incelenmesi için kontrol edilmiştir. Hücreler flask yüzeyini tamamen kapladığında kültürler tripsin enzimi yardımı ile kaldırılmıs ve pasajlanarak yeni flasklara aktarılmıştır. Flasklara aktarılarak çoğaltılan L929 hücreleri yüzeyleri kaplama oranlarına bakılarak hücrelerin yüzeyden ayrılma işlemi gerçekleştirilmiştir. Takiben hücreleri flasktan kaldırmak için içindeki vasatı atıp 2 ml PBS (1X) ile yıkanarak ardından $2 \mathrm{ml}$ TripsinEDTA eklenip 4 dakika boyunca etüvde bekletilmiştir. İnkübasyon işleminden sonra hücrelerin yüzeyden ayrılmaları mikroskop yardımı ile kontrol edildikten sonra taze besiyeri eklenerek hücreler falkon tüpe aktarılmıştır. Aktarma işleminden sonra falkon tüpler $2000 \mathrm{rpm}$ ve 2 dakika santrifüj edilmiştir. Yapılan santrifüj işleminin ardından süpernatant kısmı atılarak falkon tüpün en alt 929kısminda kalan pellet $1 \mathrm{~mL}$ taze besiyeri ile süspanse edilmiştir. Bu işlemin ardından hücre sayımı hücrelerin tripan blue ile boyandıktan sonra kuyucuk başına $10 \times 10^{4}$ hücre düşücek şekilde 96 kuyucuklu plakalara (well plate) ekilmiştir. $37^{\circ} \mathrm{C}$ 'de $\% 5$ CO2'li inkübatörde 24 saat inkübe edilen hücreler 24 saatlik inkübasyonun ardından ürünler 6 farklı konsantrasyon ve 4 tekrar olarak uygulandi. 24 saat inkübasyonun ardından platelerdeki vasat atılmış ve her kuyucuğa aynı gün hazırlanan (1mg/ml MT'T) $50 \mu$ l MT'T solüsyonundan eklenerek ve 2 saat $37^{\circ} \mathrm{C}$ 'de inkübe edilmiştir. İnkübasyon sonunda MTT solüsyonu atılıp kuyucuklara $100 \mu$ izopropanol eklenmiş ve ELISA okuyucuda 570 nm'de okutulmuştur.

\section{BULGULAR}

M'T'T testi sonucunda çıkan absorbans değerlerine göre hesaplanan \% canlılık değerleri incelendiğinde; zencefil ve zerdeçal ekstraktlarının en yüksek konsantrasyonlar1 da dahil herhangi bir konsantrasyonda toksik olmadığı, karanfil ekstraktının 1:2 konsantrasyonun toksik etkiye ve $\% 26,7$ canlilığa sahip olduğu hesaplanmıștır (Tablo 1,2,3).

Tablo 1. Zencefil ekstraktının uygulandıg1 L929 fibroblast hücrelerindeki \% canlılık değerleri

Table 1. \% viability in L929 fibroblast cells treated with ginger extract

\begin{tabular}{ll}
\hline Konsantrasyon & \% Canlılık Değerleri \\
\hline $\mathbf{1 : 2}$ & $71,8 \pm 3,72$ \\
$\mathbf{1 : 4}$ & $89,6 \pm 4,6$ \\
$\mathbf{1 : 8}$ & $94,9 \pm 5,7$ \\
$\mathbf{1 : 1 6}$ & $96,8 \pm 2,9$ \\
$\mathbf{1 : 3 2}$ & $102,5 \pm 2,5$ \\
$\mathbf{1 : 6 4}$ & $105,6 \pm 5,4$ \\
Kontrol & $100 \pm 0,04$ \\
Pozitif Kontrol-\% 20 DMSO & $18,9 \pm 2,4$ \\
\hline
\end{tabular}


Tablo 2. Zerdeçal ekstraktının uygulandığ1 L929 fibroblast hücrelerindeki \%canlılık değerleri

Table 2. \% viability in L929 fibroblast cells treated with curcuma extract

\begin{tabular}{ll}
\hline Konsantrasyon & \% Canlılık Değerleri \\
\hline $1: 2$ & $75,5 \pm 3,01$ \\
$1: 4$ & $86,9 \pm, 6,7$ \\
$1: 8$ & $95,2 \pm 3,69$ \\
$1: 16$ & $95,5 \pm 3,01$ \\
$1: 32$ & $96,8 \pm 5,17$ \\
$1: 64$ & $98,07 \pm 5,28$ \\
Kontrol & $100 \pm 0,04$ \\
Pozitif Kontrol-\% 20 DMSO & $18,9 \pm 2,4$ \\
\hline
\end{tabular}

Tablo 3. Karanfil ekstraktının uygulandığ1 L929 fibroblast hücrelerindeki \% canlilık değerleri

Table 3. \% viability in L929 fibroblast cells treated with Clove extract

\begin{tabular}{ll}
\hline Konsantrasyon & \% Canl111k Değerleri \\
\hline $\mathbf{1 : 2}$ & $26,7 \pm 5,9$ \\
$\mathbf{1 : 4}$ & $90,7 \pm 4,2$ \\
$\mathbf{1 : 8}$ & $93,4 \pm 1,7$ \\
$\mathbf{1 : 1 6}$ & $99,0 \pm 3,5$ \\
$\mathbf{1 : 3 2}$ & $109,9 \pm 4,5$ \\
$\mathbf{1 : 6 4}$ & $109,3 \pm 2,9$ \\
Kontrol & $100 \pm 0,04$ \\
Pozitif Kontrol-\%20 DMSO & $18,9 \pm 2,4$ \\
\hline
\end{tabular}

\section{TARTIŞMA}

Yapılan bu çalışma ile zerdeçal, zencefil ve karanfil'in her birinin insan fibroblast hücrelerine olan etkilerini belirleyerek toplum sağllğı üzerine etkilerinin neler olabileceğini değerlendirilmiştir. İn vitro çalışmalardaki temel prensip; organizma hücrelerinin, laboratuvar koşullarında spesifik biçimde tasarlanan kaplarda uygun nem, 1s1 ve besin kaynağ1 ortam koşullarının hazırlanarak kontaminasyondan korunmuş bir şekilde canlllı̆̆ının sürdürülmesi olup insan hücrelerini de içerebilen herhangi bir canlı hücresinin suni ortamda yaşatılabilmesi, tercih edilen bir doku ya da organdan alınan hücrelerin kullanılabilmesi bir çok etik kaygıyı geride bıraktığ1 için hücre kültürü çalışmalarının tercih sebepleri arasında yer almasını sağlamıştır (Tokur ve Aksoy 2017, Zucco ve ark. 1998). Hücre kültürünün en s1k kullanıldığ1 bilimsel sahalar aşı, kanser araştırmaları, ilaç çalışmaları ve ek olarak in vitro sitotoksisite çalışmalarıdır (Gilbert ve Boutros 2016). Diğer yandan sitotoksite terimi, hücre ölümünü tanımlayan bir kelime olup, sitotoksisite çalışmaları, araştırılan maddenin sitotoksik potansiyelini ortaya koyabilmek için yapılmaktadır. Hücre kaynaklı sitotoksisite çalışmaları, hem uygulama kolayllğ̆, hem de in vivo çalışmalardan elde edilen bilgi birikimiyle uyum göstermesi sebebiyle, hayvan deneylerine alternatif olarak da özellikle toksikoloji laboratuvarlarında sıkça kullanılır düzeye ulaşmıştır (Riss ve Moravec 2004).

Bu çalışmada sitotoksititesinin incelenmesi amaçlanan üç bitkiden ilki olan; Caryophyllaceae türleri üzerindeki önemli bir çalışmada dört farklı Caryophyllaceae türü ekstraktının sitotoksik etkilerini makrofaj hücre hatları üzerinde incelemiş ve bu çalş̧mada, ilk defa $S$. officinalis, G. trichotoma ve D. sylvestris gibi Caryophyllaceae türlerinden elde edilen ekstraktların memeli monositleri/makrofajları hücre çizgilerinin canlılığını etkilediğini ve kaspaz-3 aktivasyonu ile apoptozisi indüklediğini göstermişlerdir (Gevrenova ve ark. 2014). Potansiyel bileşiklerin veya bitki kökenli ekstrakte preparasyonunun antikanser aktiviteleri için taranması için farklı uç noktalara sahip farklı in vitro sitotoksisite analizleri kullanılmışır. En yaygın kullanilan analizler, MTT, kalsein-AM ve Hoecst 33342 analizlerini içeren boya lekelerinin kullanımını içerir. Bu boyalar, mitokondri fonksiyonunun (MTT), esteraz aktivitesinin (calceinAM) ve DNA bağlanmasının (Hoechst 33342) dolaylı olarak ölçülmesini sağlayan, devam eden hücresel süreçleri 
ortaya ç1karmalarını sağlayan bazı gösterge Özelliklerine sahiptir (Plengsuriyakarn ve ark. 2012).

Yine farklı tıbbi araştırmalarda adından söz edilen zencefilinde sitotoksititesi son derece önemlidir. Plengsuriyakarn ve ark. (2012)'nın yaptıkları çalışmada zencefil ekstraktinin normal hücrelere olan sitotoksititesinin kolanjiosellüler kanser hücrelerine göre 3.5 kat daha az olduğunu bildirmişlerdir.

Mahavorasirikul ve ark. (2010)'da zencefilin ham etanolik zerresi özünün, 34.26 ug / ml IC50 ile insan kolanjiosellüler kanser hücrelerine (CCA), CL-6 hücre hattına göre 3.5 kat karşı sitotoksik aktivite sergilediği MT'T tahlili ile göstermişlerdir (Mahavorasirikul ve ark. 2010). Bu çalışmada da zencefil ekstraktı aynı yöntemle ölçüldüğünde 1:2 olan en yüksek konsantrasyonda dahi L929 fibroblast hücrelerinin \% $71,8 \pm 3,72$ ile hala canliliklarını koruduklar1 tespit edildi. Bu sonucun Mahavorasirikul ve ark. (2010)'nin yaptığ1 çalışmadaki normal hücre hattında sitotoksik etkisinin kanser hücrelerine göre 3.5 kat daha az bulunması neticesiyle kiyaslandığında zencefilin normal metabolik hücrelerde daha az toksik olabileceği öngörülmüştür.

Yapılan bir çalışmada kurkumin ve analoglarının birçok kanser türünde etkili olduğu ifade edilmiş olup kurkuminin birden fazla hücresel sinyal yolağını uyarabildiği ve ayrıca birçok sayıda moleküler yapıyla etkileştiği konusunda görüş bildirilmiştir (Toptaş ve Alagöz 2016). Normal hücre üzerine toksik etki göstermemesi üzerine mevcut çalışmadan elde edilen veriler Toptaş ve Alagöz (2016)'ün sonuçlanyla benzerlik göstermektedir. Ayrıca Toptaş ve Alagöz (2016)'ün çalışmalarında anti-neoplastik aktivitesinin yüksek olması, düşük molekül ağırlı̆̆ına sahip olması, bu molekülü; potansiyel kemoterapötik bileşiklerin geliştirilmesinde ideal öncü molekül haline getirdiği ifade edilmektedir. Fakat biyoyararlanımın düşük olmasindan dolayı analoglarının oluşturulmasının gerektiği de vurgulanmıştır. Ancak düşük biyoyararlanıma sahip olmasından dolayı analoglarının sentezlenmesi de vurgulanmaktadir.

Gevrenova ve ark. (2014) ise, Caryophyllaceae (karanfil) türünün ekstraktlarının makrofaj hücre hatları üzerine sitotoksik etkileri üzerine etkilerini araştırdıkları bir çalışmada; tahlil edilen türlerden elde edilen ham ekstreler, makrofaj hücre hatlarına doğru sitotoksik etkiler ortaya çıkarmıştır. Gypsophila türlerinde, gypsogenin 3-0-glukuronid türevleri, gözlemlenen sitotoksisiteden sorumlu olabileceğini ve bu nedenle, Caryophyllaceae'nin ham özü, kanser hücrelerine karş1 ajanların potansiyel gelişimi için araştırmaya değer olduğunu belirtmişlerdir. Yapılan çalışmada da Caryophyllaceae'in de kanser araştırmalarında anlamlı sonuçlar verebileceğini düşündürmekle beraber zencefil ve zerdeçalın aksine Gevrenova ve ark. (2014)'nın da belirttiği şekilde sitotoksik etkilerinin olabileceği de tespit edilmiştir.

\section{SONUÇ}

Zencefil ve zerdeçal'ın sitotoksik etkisinin özellikle normal hücreler için önemsenmeyecek düzeyde olduğu tespit edilmiş olmakla beraber karanfil bitkisisin de bu ifadenin geçerli olmadığı görülmüştür. $\mathrm{Bu}$ nedenle günlük hayatımızda sıklıkla kullanılan bu baharatlara yönelik çalışmaların in vitro denemelerine ek olarak in vivo denemelerle desteklenmesi sonucuna varılmıştır.

\section{KAYNAKLAR}

Ahmed K, Shaheen G, Asif HM. Zingiber officinale Roscoe (pharmacological activity). J. Med. Plants Res. 2011; 5(3):344-348.

Aggarwal BB, Sundaram C, Malani N, Ichikawa $\mathbf{H}$. Curcumin: the Indian solid gold. In: The molecular targets and therapeutic uses of curcumin in health and disease. Ed; Aggarwal BB, Surh YJ, Shishodia S, Springer, Boston, MA. 2007; pp. 1-75.

Akram M, Shahab-Uddin AA, Usmanghani K, Hannan A, Mohiuddin E, Asif M. Curcuma longa and curcumin: a review article. Rom J Biol Plant Biol. 2010; 55(2):65-70.

Al-Snafi AE. Chemical contents and medical importance of Dianthus caryophyllus-A review. IOSR Journal of Pharmacy. 2017; 7(3):61-71.

Balaji S, Chempakam B. Toxicity prediction of compounds from turmeric (Curcuma longa L). Food Chem Toxicol.2010; 48(10):2951-2959.

Chattopadhyay I, Biswas K, Bandyopadhyay U, Banerjee RK. Turmeric and curcumin: Biological actions and medicinal applications. Curr Sci. 2004; 87:44-53.

Elmadfa I, Meyer AL. Importance of food composition data to nutrition and public health. Eur $J$ Clin Nutr. 2010; 64(S3):4-7.

Fern K. Plants for a future: Edible \& Useful plants for a healthier world. Permanent publications. Hampshire, UK. 1997.

Gevrenova R, Joubert O, Mandova T, Zaiou M, Chapleur Y, Henry M. Cytotoxic effects of four Caryophyllaceae species extracts on macrophage cell lines. Pharm biology. 2014; 52(7):919-925.

Gilbert DF, Boutros M. A protocol for a high-throughput multiplex cell viability assay. In: High-Throughput RNAi Screening. Ed; David O, Azorsa SA, Humana Press, New York, NY. 2016; pp. 75-84.

Gopal J, Anthonydhason V, Muthu M, Gansukh E, Jung S, Chul S, Iyyakkannu S. Authenticating apple cider vinegar's home remedy claims: antibacterial, antifungal, antiviral properties and cytotoxicity aspect. Nat Prod Res. 2019; 33(6):906-910.

Haniadka R, Saldanha E, Sunita V, Palatty PL, Fayad R, Baliga MS. A review of the gastroprotective effects of ginger (Zingiber officinale Roscoe). Food \& Function. 2013; 4(6):845-855.

Jolad SD, Lantz RC, Solyom AM, Chen GJ, Bates RB, Timmermann BN. Fresh organically grown ginger (Zingiber officinale): composition and effects on LPS- 
induced PGE2 production. Phytochemistry. 2004; 65(13):1937-1954.

Mahavorasirikul W, Viyanant V, Chaijaroenkul W, Itharat A, Na-Bangchang K. Cytotoxic activity of Thai medicinal plants against human cholangiocarcinoma, laryngeal and hepatocarcinoma cells in vitro. BMC Complement Altern Med. 2010; 10(1):55-62.

Mohammed MJ, Al-Bayati FA. Isolation and identification of antibacterial compounds from Thymus kotschyanus aerial parts and Dianthus caryophyllus flower buds. Phytomedicine. 2009; 16(6-7):632-637.

Park EJ, Pezzuto JM. Botanicals in cancer chemoprevention. Cancer and Metastasis Reviews. 2002; 21(3-4):231-255.

Plengsuriyakarn T, Viyanant V, Eursitthichai V, Tesana S, Chaijaroenkul W, Itharat A, Na-Bangchang, K. Cytotoxicity, toxicity, and anticancer activity of Zingiber officinale Roscoe against cholangiocarcinoma. Asian Pac J Cancer. 2012; 13(9):4597-4606.

Polunin O, Huxley A, Everard B. Flowers of the Mediterranean. Chatto and Windus, London.1965.

Riss TL, Moravec RA. Use of multiple assay endpoints to investigate the effects of incubation time, dose of toxin, and plating density in cell-based cytotoxicity assays. Assay Drug Dev Technol. 2004; 2(1):51-62.

Shukla Y, Singh M. Cancer preventive properties of ginger: a brief review. Food Chem Toxicol. 2007; 45(5):683-690.

Tokur O, Aksoy A. In vitro sitotoksisite testleri. Harran Üniv Vet Fak Derg. 2017; 6(1):112-118.

Toptaş B, Alagöz ZA. Anticarcinogenic Effects of Curcumin and It's Analogs. Ankara Ecz Fak Derg. 2016; 40(2):5882

Tyler VE. The honest herbal: a sensible guide to the use of herbs and related remedies. George F. Stickley Company, New York, USA.1993.

Zhu JS, Halpern GM, Jones K. The scientific rediscovery of an ancient Chinese herbal medicine: Cordyceps sinensis Part I. The Journal of alternative and complementary medicine. 1998; 4(3):289-303.

Zucco F, De Angelis I, Stammati A. Cellular models for in vitro toxicity testing. In: Animal Cell Culture Techniques. Ed; Clynes M, Springer, Berlin, Heidelberg. 1998; pp. 395-422. 